\title{
TAX AVOIDANCE PRACTICE, CORPORATE GOVERNANCE, AND FIRM VALUE
}

\author{
$\mathbf{1}^{\text {st }}$ Afriyanti Hasanah \\ Managerial Accounting Study Program \\ Politeknik Negeri Batam \\ Batam, 29461, Indonesia \\ E-mail: afriyanti@ polibatam.ac.id ${ }^{1}$
}

\author{
$2^{\text {nd }}$ Juliana Br Sirait \\ Managerial Accounting Study Program \\ Politeknik Negeri Batam \\ Batam, 29461, Indonesia \\ siraitjuliana@gmail.com
}

\author{
$3^{\text {rd }}$ Dina Yeni Martia \\ Finance Department \\ ,National Yunlin University of Science \\ and Technology \\ 123 University Road, Section 3, Douliu \\ City, Yunlin County, 64002, Taiwan \\ d10624056@gemail.yuntech.edu.tw
}

\begin{abstract}
This study aims to examine the effect of tax avoidance practices, corporate governance on the value of companies in manufacturing companies listed on the Indonesia Stock Exchange (IDX) for the period 20132017. Tax avoidance practices are proxied by effective tax rate. Corporate governance is proxied by an independent board of commissioners and an external auditor. The company value is proxied by Tobins $Q$. This study uses secondary data with a purposive sampling collection technique. The sample used in this study was 280 companies. The research data were analyzed by panel data regression analysis using Eviews 9. The results of the study found that corporate governance based on external auditors had a significant positive effect on firm value, while tax avoidance and independent board of commissioners did not influence the value of the company.
\end{abstract}

Keywords: Tax Avoidance, Corporate Governance, and Firm Value

\section{INTRODUCTION}

Tax is the most potential state income, because it is used for general expenditure, so it does not provide direct benefits to the community [15]. On the other hand for the companies, tax is a burden because it acts as a deduction from profits, so companies try to reduce the tax burden. The form of tax management that is often carried out by companies is the existence of tax avoidance activities by using the weak points of tax rules so as to reduce the tax burden owed by taxpayers [13]. These activities can provide opportunities for management to minimize the tax burden and increase company profits.

The indicator used to see the high and low values of the company can be known through taxes paid by the company. Companies with optimal profits can attract investors because the couch has good performance [19]. This will create a wealth of increasing shareholder. Conversely the practice of tax evasion causes information regarding financial statements to decrease, this results in a decrease in the value of the company. This phenomenon was marked by information from the Indonesian Secretary General of the Forum for Budget Transparency (FITRA) acknowledging that it was estimated that every year there were Rp110 trillion in tax evasion figures, most of which were business entities, namely $80 \%$ and the rest were individuals. Tax avoidance efforts can provide space to carry out corporate opportunism steps by manipulating profits or in other words tax avoidance related to corporate governance [8].

The existence of such governance is expected to be able to safeguard investors from different interests, there by encouraging management to be more transparent to company owners and to reduce conflicts that occur in the company [3]. The measurements of corporate governance in this study are independent commissioners and external auditors. An independent commissioner can give a view on controlling a company in order to create a better management of the company including determining effective tax rates. In addition, transparency of the owner can also be achieved by the effectiveness of the audit function. According to several sources, the audits conducted by KAP the Big Four are more reliable because they have a low level of fraud so they are predicted to be able to show the true value of the company [2].

Several previous studies have been conducted but found inconsistent results. Research [4] found that there was no significant effect of tax planning on firm value, while the results of [1] state that there is a significant positive effect of tax avoidance on firm value. In addition, other indicators that influence the value of the company are corporate governance. The results of the observation [11] explained that the proportion of the independent commissioners and external auditors had a significant positive effect on firm value. The difference between this research and previous research is that corporate governance variables as independent variables measured by independent commissioners and external auditors, next use manufacturing companies because this type of company is the biggest contributor to tax revenues and uses the latest year, 2013-2017 so that there are no similarities thorough with previous research. Based on these explanations the title that the researcher took was: "Tax Avoidance Practice, Corporate Governance and Firm Value". 


\section{BASIC THEORY AND DEVELOPMENT OF HYPOTHESIS}

\section{A. Theoretical Basis}

a. Agency Theory

Agency theory suggests that the owner gives trust to the agent to carry out all operational activities that occur in the company [9] because of differences in interests The manager as an agent certainly wants to maximize his own interests by carrying out improper actions, this is what can cause the existence of information asymmetry, namely the emergence of conflicts between owners and managers. One of the concerns is company policy regarding taxes. The taxation system in Indonesia which adheres to self assessment is that companies can calculate and report on their own taxes paid can provide an opportunity for managers (agents) to manipulate taxable income that can affect the value of a company, so that good management is needed to achieve the desires of company owners.

\section{b. Signal Theory}

The signal theory is defined as an encouragement for companies to signal to outsiders [14]. The information can provide positive and negative signals. Positive signals can be seen from the profit information generated. The higher profits will increase the value of the company, due to the existence of tax avoidance activities so as to signal to investors with an increase in the value of shares [12]. On the other hand tax avoidance activity becomes a negative signal if it raises additional costs in the future such as planning costs and penalty fees [16].

\section{c. Development of Hypotheses}

a. Effect of Tax Avoidance on Firm Value

The decision of an investment made by an investor considers tax information carried out by a company. The existence of tax avoidance behavior has the potential to trigger agency conflicts between the interests of managers and owners. Based on the activity of the reason companies conduct activities to minimize tax avoidance tax liabilities paid as a form of behavior opportunistic managers should provide accurate and relevant information to investors [1]. Research conducted by [6] found a negative relationship between tax avoidance and firm value.

$\mathbf{H}_{1}$ : Tax Avoidance has a negative effect on Firm Value

b. Effect of the Independent Board of Commissioners on Firm Value

Independent commissioners aim to balance in decision making especially in the context of protecting minority shareholders and other related parties. The increasing number of independent commissioners indicates that the independent board of commissioners performs a function of supervision and good coordination within the company. The results of the research conducted by [11] explained that the number of independent commissioners had a significant effect on the value of the company.
$\mathbf{H}_{2}$ : The Independent Board of Commissioners has a positive effect on Firm Value

\section{c. Effect of External Auditors on Firm Value}

Every company certainly wants high-quality audit quality to find out about misstatements reported in financial statements. One party that can bridge the conflict that arises between the agent and the owner is the auditor. The principal believes in the quality of the audit carried out by the Big Four KAP because it gets a good reputation with International standards, so that the financial statements reported have high credibility. The statement supports the results of research conducted by [11].

H3: External Auditors have a positive effect on Firm Value

d. Effects of Tax Avoidance, Independent Board of Commissioners, and External Auditors on Firm Value

Companies in carrying out their operational activities certainly want maximum profit. The alternative that can be used to achieve that is by the existence of tax avoidance, which describes the corporate tax will look small while the resulting profit becomes large. In addition, the importance of governance in a company serves to guarantee company activities and financial reporting in accordance with applicable rules.

An adequate composition of independent commissioners can maximize company performance, coupled with supervision of the functions of external auditors who can assist the board of commissioners in carrying out their supervisory functions in the financial reporting process. The application of good corporate governance with a work system will increase the value of the company as reflected in the increasing stock price.

H4: Tax Avoidance, Independent Board of Commissioners, and External Auditors together have the same effect on Firm Value

\section{RESEARCH METHODS}

\section{A. Population and Samples}

The results of the research are manufacturing companies listed on the IDX using a purposive sampling method with the following criteria: (1) manufacturing companies listed on the Indonesia Stock Exchange in 2013-2017 and publishing financial reports and annual reports in full, (2) presenting reports in Rupiah currency unit (3) has a positive pre-tax profit value.

\section{B. Operational Variables and Measurement Definitions}

a. Firm Value

Firm value is proxied by the Tobin's Q formula as follows:

$$
\mathrm{Q}=\frac{(\mathrm{MVS}+\mathrm{D})}{\mathrm{TA}}
$$

b. Tax Avoidance

Tax avoidance measured using the effective tax rate as well as on the following formula:

Effective Tax Rate $=\underline{\text { Total Income Tax Expense }}$ Pre Tax Income 
c. Independent Board of Commissioners

This variable is measured by the following formula: DKI $=\sum$ Independent Board of Commissioners $\sum$ For the Board of Commissioners

\section{d. External Auditor}

The external auditor in this study uses a dummy variable, where companies that use the Big Four KAP will be given a value of 1 while companies that do not use the Big Four KAP will be given a value of 0 .

\section{Control Variables}

\section{a. Return on Equity}

This variable is measured by the following formula: Return on Equity $=\quad$ Net Income Shareholders' Equity

b. Leverage

This variable is measured by the following formula: Debt To Assets Ratio = Total Debts

\section{Total Assets}

\section{RESULT AND DISCUSSION}

\section{A. Sample Characteristics}

Based on the sampling phase in Table 1, then get the number of companies manufacturing sector as the study population were registered in the Stock Exchange in 2013 to 2017 as many as 143 companies. The final sample of the study which fulfills the criteria is 56 companies, so the total number of observations during the period 2013-2017 is 280 sample data.

TABLE I. NUMBER OF STUDY SAMPLE

\begin{tabular}{lc}
\hline \multicolumn{1}{c}{ Company Indications } & Total \\
\hline Manufacturing companies listed on the Indonesia Stock & 143 \\
$\begin{array}{l}\text { Exchange for the period 2013-2017 } \\
\text { Companies that use currencies other than Rupiah (Rp) }\end{array}$ & $(29)$ \\
$\begin{array}{l}\text { Companies that have a negative pre-tax income value } \\
\text { Companies that do not publish financial reports and } \\
\text { annual reports in a row during the 2013-2017 research } \\
\text { year }\end{array}$ & $(18)$ \\
\hline \multicolumn{2}{l}{ Companies selected as samples per year } \\
\hline Total Samples for the period 2013-2017 & $\mathbf{5 6}$ \\
\hline \hline
\end{tabular}

Source: Data processed by yourself

B. Descriptive Statistics

TABLE II. DESCRIPTIVE STATISTICS

\begin{tabular}{lccccc}
\hline & Q & TA & DKI & ROE & LEV \\
\hline Mean & 2.4423 & 0.3291 & 0.3997 & 0.1745 & 0.3940 \\
Maximum & 23.2857 & 5.7749 & 0.8000 & 1.4353 & 0.8809 \\
Minimum & 0.3041 & 0.0124 & 0.2500 & -0.1391 & 0.0691 \\
Std. Dev. & 3.2138 & 0.4854 & 0.1041 & 0.2280 & 0.1799 \\
Sampel (N) & & & 280 & & \\
\hline
\end{tabular}

Source: Results of processing Eviews 9
Based on the descriptive statistical test in table II described from $\mathrm{N}$ as many as 280 sample companies, the maximum value of the variable Tobin's $q$ is 23.2857 and the minimum value is 0.3041 , the tax avoidance variable has a maximum value of 5.7749 and a minimum value of 0.0124 , variable the independent board of commissioners has a maximum value of 0.8000 and a minimum value of 0.2500 . The control variable in this study namely return on equity has a maximum value of 1.4353 and a minimum value of $\quad-0.1391$ and the leverage variable has a maximum value of 0.8809 and a minimum value of 0.0691 .

TABLE III. VARIABLES OF EXTERNAL AUDITOR

\begin{tabular}{ccc}
\hline Eksternal Auditors & Frequency & $\sum$ \\
\hline Big Four (1) & $48 \%$ & 133 \\
Non Big Four (0) & $52 \%$ & 147 \\
\hline$\sum$ & $100 \%$ & 280 \\
\hline
\end{tabular}

Source: Results of processing Eviews 9

Independent variables that are proxied by external auditors are measured by dummy variables, namely with a maximum value of 1 representing the company the audited by the Big Four KAP and the minimum value of 0 representing the company audited by KAP other than the Big Four. It can be seen from table 3 the average company uses Big Four KAP service by $48 \%$, which is 133 companies and the remaining $52 \%$ as many as 147 companies.

\section{Classic Assumption Test \\ Multicollinearity Test}

Multicollinearity test aims to examine the linear relationship between independent variables. The following is attached to the test results table:

\section{TABLE IV. MULTICOLLINEARITY TEST}

\begin{tabular}{rcccc}
\hline & TA & DKI & ROE & LEV \\
\hline TA & 1.000000 & 0.001237 & -0.147171 & 0.037208 \\
DKI & 0.001237 & 1.000000 & 0.477300 & 0.239669 \\
ROE & -0.147171 & 0.477300 & 1.000000 & 0.199335 \\
LEV & 0.037208 & 0.239669 & 0.199335 & 1.000000 \\
\hline
\end{tabular}

Source: Results of processing Eviews 9

Based on table IV, the tolerance value for each independent variable is $<10$, then all independent variables are free from multicollinearity which means there is no relationship between the independent variables studied.

\section{Heterocedasticity Test}

This study uses the Glejser test with the provision that if the significance value or Sig (2-tailed) is greater than 0.05 then the problem of heteroscedasticity does not occur. From the test results obtained the probability value of each independent variable which is greater than 0.05 , the 
regression model does not experience the problem of heteroscedasticity.

TABLE V. HETEROCEDASTICITY TEST Dependent Variable: RESABS

\begin{tabular}{ccccc}
\hline Variable & Coefficient & Std. Error & t-Statistics & Prob. \\
\hline C & 0.286514 & 0.285402 & 1.003897 & 0.3165 \\
TA & 0.043637 & 0.059040 & 0.739104 & 0.4606 \\
DKI & 0.437925 & 0.528757 & 0.828217 & 0.4084 \\
ROE & 0.633337 & 0.384512 & 1.647119 & 0.1010 \\
LEV & -0.561767 & 0.457979 & -1.226620 & 0.2213 \\
\hline Source: Results of processing Eviews & & &
\end{tabular}

\section{Data Analysis}

Based on the results of hypothesis testing between independent variables, control variables and dependent variables then the summary of the results of hypothesis testing can be seen in the tables following this:

$$
\text { TABLE VI. HYPOTHESIS } 1 \text { TEST RESULTS }
$$

\begin{tabular}{lccc}
\hline \multicolumn{1}{c}{ Variable } & Coefficient & $\begin{array}{c}\text { t- } \\
\text { Statistics }\end{array}$ & Prob. \\
\hline C & -0.9484 & -3.1421 & 0.0019 \\
TA & 0.0928 & 0.7072 & 0.4801 \\
ROE & 4.0847 & 16.8821 & 0.0000 \\
LEV & -0.9290 & -3.1095 & 0.0021 \\
& & & \\
R-squared & & & 0.8546 \\
Adjusted & & & 0.8164 \\
R-squared & & & 0.0000 \\
Prob(F-statistic) & & & Fixed \\
Model & Test & & \\
\hline$* *$ Significant at the level of 5\% & & \\
\hline
\end{tabular}

Source: Results of processing Eviews 9

\section{Effect of Tax Avoidance on Firm Value}

Based on the results of the $\mathrm{H} 1$ test, it shows that there is no effect of tax avoidance on firm value, so hypothesis 1 is not supported. These results indicate that the practice of tax avoidance does not reduce the value of the company in the eyes of investors, because it is considered to still comply with legal taxation rules. In general, investors prefer decisions in investing by looking at a stable or high profit, so that the presence or absence of tax avoidance does not affect investor decisions in investing. This result is in line with the research conducted by [4], but not in line with the research carried out by [5].

\section{TABLE VII. HYPOTHESIS 2 TEST RESULT}

\begin{tabular}{lccc}
\hline \multicolumn{1}{c}{ Variable } & Coefficient & $\begin{array}{c}\text { t- } \\
\text { Statistics }\end{array}$ & Prob. \\
\hline C & -0.9440 & -2.1641 & 0.0315 \\
DKI & 0.0978 & 0.1895 & 0.8498 \\
ROE & 4.0308 & 15.4264 & 0.0000 \\
\hline
\end{tabular}

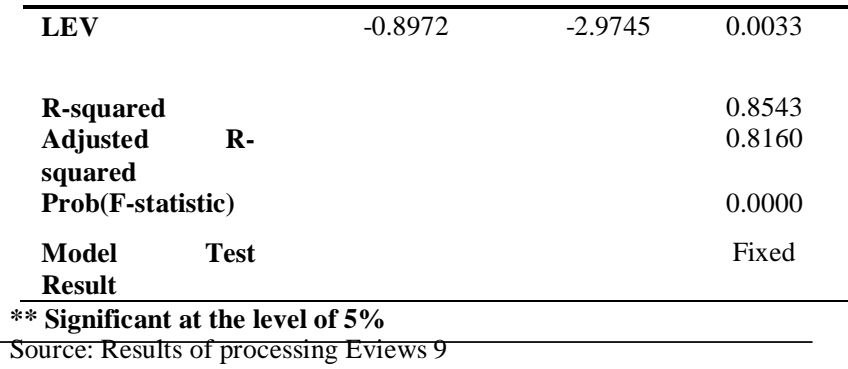

\section{Effect of the Independent Board of Commissioners on Firm Value}

Based on the results of testing hypothesis 2, it shows that the independent board of commissioners has no effect on company value, so hypothesis 2 is not supported. This shows that the size of the proportion of independent commissioners does not guarantee that the performance of a company is getting better, considering the function of an independent board of commissioners is limited to a supervisory function. The supervision carried out by the independent board of commissioners does not hinder the manager's behavior in maximizing his interests so that the target in increasing the value of the company is difficult to achieve. These results indicate consistent with research conducted by [17] but not in line with the research done by [11].

TABLE VIII. HYPOTHESIS 3 TEST RESULT

\begin{tabular}{lccc}
\hline \multicolumn{1}{c}{ Variable } & Coefficient & $\begin{array}{c}\text { t- } \\
\text { Statistics }\end{array}$ & Prob. \\
\hline C & -0.8975 & -3.3491 & 0.0010 \\
AU_EKS & 0.3152 & 5.7121 & 0.0000 \\
ROE & 3.6339 & 15.5609 & 0.0000 \\
LEV & -0.6648 & -2.4168 & 0.0165 \\
& & & \\
R-squared & & 0.8730 \\
Adjusted & R- & & 0.8397 \\
Squared & & 0.0000 \\
Prob(F-statistic) & & Fixed \\
Model Test Result & & \\
\hline ** Significant at the level of 5\% & \\
\hline Source: Results of processing Eviews 9 & \\
\hline
\end{tabular}

\section{Effect of External Auditors on Firm Value}

Based on the results of testing hypothesis 3 shows that the external auditor has an influence on the value of the company, so that hypothesis 3 is supported. The existence of an external auditor as an independent party in a company gives a positive influence, meaning that if the company's financial statements are audited by auditors from external sources, it will further increase the value of the company. The results of this study see that the market responds to audits conducted by KAP affiliated with KAP International has a good reputation so that it is one of the considerations of investors in assessing the financial reporting quality of a company. This result is consistent with the research 
conducted by [7] but contradicts the research conducted by [10].

TABLE IX. HYPOTHESIS 4 TEST RESULT

\begin{tabular}{lccc}
\hline \multicolumn{1}{c}{ Variable } & Coefficient & $\begin{array}{c}\text { t- } \\
\text { Statistics }\end{array}$ & Prob. \\
\hline C & -0.9975 & -2.4166 & 0.0165 \\
TA & 0.0589 & 0.4756 & 0.6348 \\
DKI & 0.0907 & 0.1865 & 0.8522 \\
AU_EKS & 0.3141 & 5.6633 & 0.0000 \\
ROE & 3.6374 & 13.8629 & 0.0000 \\
LEV & -0.7084 & -2.4371 & 0.0156 \\
& & & \\
R-squared & & & 0.8732 \\
$\begin{array}{l}\text { Adjusted } \\
\text { squared } \\
\text { Prob(F-statistic) }\end{array}$ & & & 0.8384 \\
Model Test Result & & & 0.0000 \\
\hline$* *$ Significant at the level of 5\% & & Fixed \\
\hline
\end{tabular}

Source: Results of processing Eviews 9

Effects of Tax Avoidance, Independent Board of Commissioners, and External Auditors on Firm Value

Based on the results of testing hypothesis 4 shows that tax avoidance, independent board of commissioners, and external auditors jointly influence the value of the company so that hypothesis 4 is supported. As is known as one of the considerations of investors in making investment decisions made by looking at the distribution of dividends from profits generated by the company. In addition, the number of independent commissioners who can guarantee the supervision of a company more effectively and to be able to maintain public confidence in the report presented is certainly required to disclose transparent financial information. This can happen if the company uses auditor services with international standardization through the presence of the Big Four KAP.

\section{CONCLUSION}

Based on the explanation of the results above, he can draw conclusions as follows: tax avoidance and independent board of commissioners do not affect the value of the company. This happens because in general investors prefer investment decisions by looking at stable or high profits, so that the alleged tax avoidance does not affect investors in making investment decisions. In addition, the size of the proportion of independent commissioners in the company is not a guarantee of the company's performance will be better, so the proportion of independent commissioners is only limited to meeting the set regulatory requirements.

The external auditor variable has an influence on company value, meaning that the higher the quality of the external auditor, increasing public trust in the transparency of information provided by the company followed by increasing company value and then simultaneously tax avoidance, independent board of commissioners and external auditors influence the value of the company.
Suggestions for further research are to add a longer time span, proxy tax avoidance not only uses effective tax rate measurement, but can add other variables besides effective tax rate such as cash effective tax rate and current effective tax rate and add other research variables that are thought to be able to affect company value such as company size that can be categorized by small, medium, or large size.

\section{REFERENCES}

[1] Anggoro, S. T. (2015). Analisis Pengaruh Perilaku Penghindaran Pajak Terhadap Nilai Perusahaan Dengan Transparansi Sebagai Variabel Moderating. Diponegoro Journal of Accounting, 4(4), 1-10.

[2] Annisa, N. A., \& Kurniasih , L. (2012). Pengaruh Corporate Governance Terhadap Tax Avoidance. Jurnal Akuntansi dan Auditing, 8(2), 95-189.

[3] Damayanti, F. (2015). Pengaruh Komite Audit, Kualitas Audit, Kepemilikan Institusional, Risiko Perusahaan dan Return on Assets Terhadap Tax Avoidance. Jurnal Bisnis dan Manajemen, 5(2), 187206.

[4] Dewanata, P. (2017). Pengaruh Perencanaan Pajak Terhadap Nilai Perusahaan Dengan Kualitas Corporate Governance Sebagai Variabel Moderasi Studi Empiris Pada Perusahaan Manufaktur Yang Terdaftar di BEI Pada Tahun 2012-2014. Diponegoro Journal of Accounting, 6(1), 1-7.

[5] Dinah, A. F., \& Darsono. (2017). Pengaruh Tata Kelola Perusahaan, Profitabilitas dan Penghindaran Pajak Terhadap Nilai Perusahaan. Diponegoro Journal of Accounting, 6(3), 1-15.

[6] Hanlon, M., \& Heitzman, S. (2010). A Review of Tax Research. Journal of Accounting and Economics, 50, 127-128.

[7] Herawaty, V. (2008). Peran Praktek Corporate Governance Sebagai Moderating Variable dari Pengaruh Earnings Management Terhadap Nilai Perusahaan. Jurnal Akuntansi dan Keuangan, 10(2), 97-108.

[8] Inanda, T. U. (2018). Pengaruh Penghindaran Pajak Terhadap Nilai Perusahaan Yang Dimoderasi Oleh Corporate Governance dan Kepemilikan Mayoritas. Jurnal Akuntansi, 12(2), 126-145.

[9] Jensen, M. C., \& Meckling , W. H. (1976). Theory of The Firm: Managerial Behavior, Agency Costs and Ownership Structure. Journal of Financial Economics, 3(4), 305-306.

[10] Jusny, F. (2014). Pengaruh Konservatisme Akuntansi Terhadap Nilai Perusahaan Dimoderasi Oleh Good Corporate Governance (Studi Empiris Pada Perusahaan Sektor Retail Trade Yang Listing di Bursa Efek Indonesia). Jurnal Audit dan Akuntansi Fakultas Ekonomi Universitas Tanjungpura, 3(1), 29-52.

[11] Perdana, R. S. (2014). Analisis Pengaruh Corporate Governance Terhadap Nilai Perusahaan. Diponegoro Journal of Accounting, 3(3), $1-13$.

[12] Prasiwi, K. W. (2015). Pengaruh Penghindaran Pajak Terhadap Nilai perusahaan Dengan Transparansi Informasi Sebagai Variabel Pemoderasi. Skripsi Program Studi Akuntansi Fakultas Ekonomi dan Bisnis Universitas Di Ponegoro.

[13] Silviana, \& Widyasari. (2018). Faktor-faktor Yang Mempengaruhi Tax Avoidance Pada Perusahaan Manufaktur. Jurnal Multiparadigma Akuntansi Tarumanegara, 1(1).

[14] Spence, M. (1973). Job Market Signalling. The Quarterly Journal of Economics 87(3), 355-374.

[15] Suandy, E. (2011). Perencanaan Pajak Edisi 5. Salemba Empat.

[16] Wang, X. (2010). Tax Avoidance, Corporate Transparency and Firm Value. Journal of Financial Economics.

[17] Wardoyo, \& Veronica, T. M. (2013). Pengaruh Good Corporate Governance, Corporate Social Responsibility \& Kinerja Keuangan Terhadap Nilai Perusahaan. Jurnal Dinamika Manajemen, 4(2), 132149.

[18] Widyasari, N. A., Suhadak, \& Husaini , A. (2015). Pengaruh Good Corporate Governance (GCG) dan Pengungkapan Corporate Social Responsibility (CSR) Terhadap Nilai Perusahaan Studi Pada Perusahaan Manufaktur Yang Terdaftar di BEI Periode 2011-2013. Jurnal Administrasi Bisnis (JAB), 26(1), 1-11. 
[19] Winasis, S. E. (2017). Pengaruh Gender Diversity Eksekutif Terhadap Nilai Perusahaan Tax Avoidance Sebagai Variabel Intervening : Studi Kasus Pada Perusahaan Pertambangan Yang Terdaftar di BEI Tahun 2012-2015. Diponegoro Journal of Accounting, 6(1), 1-14. 